\title{
The Legend of Saint Kinga - Patroness of Krakow Miners
}

The Mining-Geology-Petroleum Engineering Bulletin DOI: $10.17794 / \operatorname{rgn} .2015 .2 .8$

Story about issue cover picture

\section{Gordan Bedeković ${ }^{1}$}

${ }^{1}$ University of Zagreb, Faculty of Mining, Geology and Petroleum Engineering, Pierottijeva 6, 10000 Zagreb

Long, long ago, Prince Boleslaw Wstydliwy (1226-1279; Figure 1) was the ruler of Poland. He decided to ask the princess of Hungary, Kinga to marry him. Consequently, he sent a message to the court of the Hungarian King Bela IV. Also, he ordered to give an engagement ring to princess Kinga. She agreed to become a Polish princess.

Saint Kinga (1234-1292; Figure 2) was born in Esztergom, Kingdom of Hungary and she was daughter of Hungarian King Bela IV and Maria Laskarina.

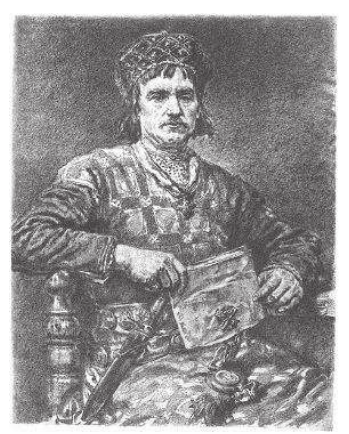

Figure 1: Prince Boleslaw Wstydliwy sculpture

Kinga's father wanted to give her gold and jewels as dowry, but the princess said that this would not be good, since the Polish king was wealthy and his county lived in prosperity. Kinga's father asked her: „So, what dowry do you want, my daughter?" After some thought, the princess asked her father to give them salt, which would gain the appreciation of Boleslaw and his subjects. Namely, salt at that time was extremely appreciated.
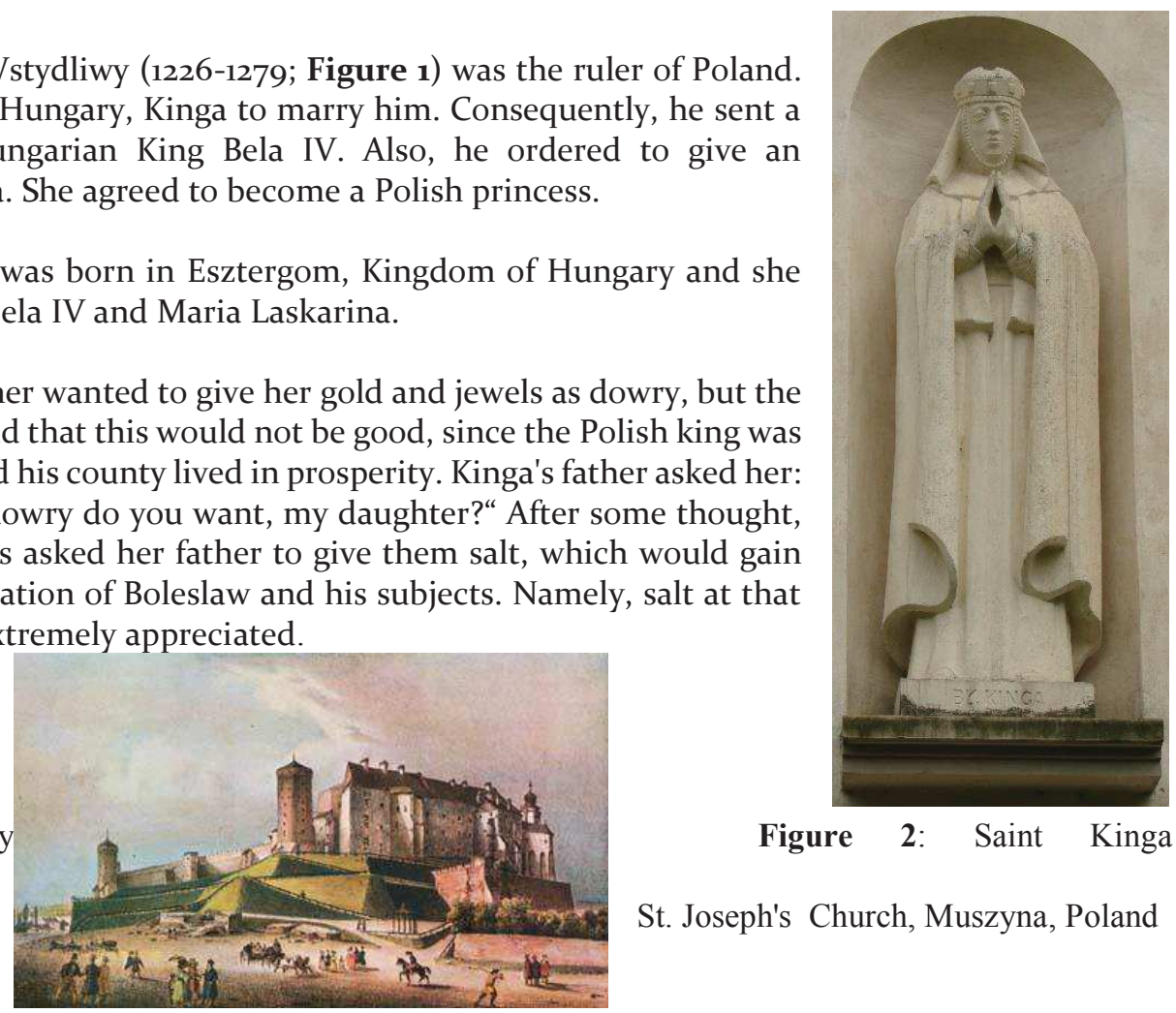

Figure 2: Saint Kinga St. Joseph's Church, Muszyna, Poland

Figure 3: Wawel Hill

Certainly, a father wanting to meet the request of his daughter, took her to the mine in Marumuresz and said: „You have what you asked, here are rich salt deposits“. However, the king was pensive, because he did not know how to move all the salt to the Polish mine. She lifted her eyes, asking God for advice and after a while she knew what to do. She removed her engagement ring from Boleslaw and threw it into the mine shaft. Courtiers who saw it were a little surprised, but they said nothing.

Soon, Kinga went to the court of King Boleslaw, where he waited for her arrival. Shortly after the wedding took place, and all the knights of the Malopolska and nobles appeared. The King lived in the Wawel Hill Castle in Krakow (Figure 3). After several days, seeking to find her dowry, she asked her husband to show her the kingdom. So the whole procession came, and the king showed her the beautiful land of his principality.

At one moment, Kinga told them to the stop and directed her servants to dig in the ground. When the attendants came upon a rock and said that further digging was impossible. Kinga ordered to split off a piece of rock. One of the 
peasants gave Kinga a white piece of rock, which was a lump of salt. She ordered them to split it and her engagement ring fell out of the lump. Then they all understood what a dowry her father gave her and that the ring, which she threw into the mine in Marumuresz, brought precious salt to Poland. Since then, the mine in Wieliczka is famous for its rich salt deposits. Princess Kinga wisely ruled the Polish people for a long time.

\section{Internet sources:}

Figure 1: https://pl.wikipedia.org/wiki/Boles\%C5\%82aw_V_Wstydliwy\#/media/File:Boleslaw_V_Wstydliwy.jpg Figure 2:

https://en.wikipedia.org/wiki/Kinga_of_Poland\#/media/File:\%C5\%9Awi\%C4\%99ta_Kinga \%28sculpture\%29.jpg Figure 3: http://www.krakow-info.com/castle.htm 